\title{
BARRIERS IN FINANCING MICROENTERPRISES FROM THE PERSPECTIVE OF CZECH AND SLOVAK MICROENTREPRENEURS
}

\author{
Mehmet CIVELEK ${ }^{\left({ }^{1}\right.}{ }^{\star}$, Aleksandr KLJUČNIKOV ${ }^{\left(\mathbb{D}_{2}\right.}$, \\ Peter KRIŠTOFÍK ${ }^{3}$, Zoltán ROZSA ${ }^{4}$ \\ ${ }^{1}$ Faculty of Management and Economics, Tomas Bata University in Zlin, \\ Mostní, 5139, 760 01, Zlin, Czech Republic \\ ${ }^{2}$ Faculty of Economics and Business, Pan-European University \\ Tematinska, 10, 851 05, Bratislava, Slovakia \\ ${ }^{3}$ Faculty of Economics, University of Matej Bel in Banska Bystrica, \\ Tajovského 10, 975 90, Banská Bystrica, Slovakia \\ ${ }^{4}$ Faculty of Social and Economic Relations, Alexander Dubček University of Trenčín, \\ Študentská 1638/3, 91150 Trenč́n, Slovakia
}

Received 11 June 2018; accepted 22 January 2019

\begin{abstract}
This paper compares how Czech and Slovak microentrepreneurs perceive the volume and ease of access to finance that they face. Having an adequate number of sources of finance and easier access to them can help improve both enterprise and country performance. Chi-square and Z score tests for population proportions were used to test hypotheses. 740 microenterprises from Czech Republic and 287 microenterprises from Slovakia were included for the analyses that were performed by this study. The results show that Czech microentrepreneurs feel they have more sources of finance and have easier access to them than their Slovak counterparts. These differences may in part be linked to other factors such as the experience and age of microentrepreneurs and micro-firms, amount of business loans and microfinancing organizations, credit interest rates and credit rejection rates, the relative degree of economic freedom, the volume of government guarantees, relative GDP levels, the quality of business environment and ease of doing business. Additionally, The Moran's I spatial autocorrelation index was performed to evaluate influence of location on the perception of Czech and Slovak microenterprises that were located in different regions of both countries. The paper also discusses the results' policy implications for governments and financial institutions.
\end{abstract}

Keywords: microenterprises, SMEs, bank financing, microfinancing, Slovakia, Czech Republic, financial constraints.

JEL Classification: G21, L26, O16.

${ }^{\star}$ Corresponding author. E-mail: civelek@fame.utb.cz 


\section{Introduction}

Although microenterprises are very small businesses, they have very substantial benefits for the growth of economies, employment and income generation. The unit of research is the microenterprise: defined as a firm with up to 9 employees, and an annual turnover of less than 2 million EUR (European Commission, 2016). Most of microenterprises are operated in rural regions by an owner who is the only employee and the founder of a firm (Larson \& Shaw, 2001). Because they may help to create a competitive environment, improve entrepreneurial competency, and encourage innovation, microenterprises are a key driver of the European economy (Kozubikova, 2016). They make a noteworthy contribution to the Czech and Slovak economies. In Slovakia $96.8 \%$ of the enterprises are microenterprises. They account for $41.1 \%$ of employment and $27 \%$ of the value added. In the Czech Republic $96.1 \%$ of firms are microenterprises. They account for $31.7 \%$ of the total workforce and $20.1 \%$ of the value added. Because of the relative sizes of the two economies the Czech microenterprise sector provided the larger numbers of jobs and amount of value added (EC, 2016a).

In order to grow, microenterprises need capital to buy assets, to finance their operational activities and meet their living costs. Financial capital can be accessed from various external and internal resources, such as debt and personal savings (Atmadja, Jen-Je, \& Sharma, 2016; Bhaird \& Lucey, 2010; Gbandi \& Amissah, 2014). Pecking order theory emphasizes the existence of a hierarchy in the selection of these resources: enterprises look first for financing from internal and then from external sources, because of the higher costs of external financing (Osei-Assibey, Godfred, Bokpin, \& Twerefou, 2012; Daskalakis, Jarvis, \& Schizas, 2013; Ryan, O’Toole, \& McCann, 2014). But because of insufficient internal sources, microenterprises usually look for financing from external sources. But whichever financing option they choose microenterprises face more obstacles than larger enterprises.

For Slovak SMEs the European Union provided a fund of around 11.5 billion Euros in 2007-2013. Other institutions and programs that also provide capital for Slovak SMEs include the EXIM Bank, the Slovak Guarantee and Development Bank, the NADSMB (Bondareva \& Zatrochova, 2014) the Agency for Entrepreneurship and Innovation (API), the Slovak Business Agency (SBA) and the JEREMIE initiative. In comparison the Czech Republic has been implementing its "Small and Medium Sized Enterprises Support Strategy 2014-2020". This includes the Operational Program for Enterprise and Innovations for Competitiveness (OPEIC), the Innovative Businesses Program (INOSTART), and involves the Czech-Moravian Guarantee and Development Bank and the Czech Export Bank. According to Technology Agency of Czech Republic (2015) provides supports for enterprises and research organizations by ALPHA program that gives fund around 550 million euros and $52 \%$ of this amount has subsidized to the SMEs. There are also other programs that Technology Agency of Czech Republic (n.d.) offers namely, Alfa, Gama, Epsilon, Kappa and Delta. These programs mainly aim to encourage research, innovation activities of enterprises and to create international relationship between Czech and foreign firms or research entities. For instance, Kappa program creates opportunities to increase competitiveness of entities from Norway, Ireland, Liechtenstein and Czech firms to make cooperation between each other. In line with this objective, Kappa program subsidizes approximately 32 million 
euros for enterprises in those countries. Another program has operated in Czech Republic since 2017 by Czech-Moravian Guarantee and Development Bank (CMGDB) namely Expansion. The objective of this program is to provide easier credit conditions such as giving credit with reduced interest rates and supporting projects of SMEs that are located in rural areas.

Focusing on impediments to accessing capital, the 2016 interest rate for Slovak SMEs was $3.10 \%$ compared to $2.50 \%$ for Czech SMEs (OECD, 2018). The percentage of Czech SMEs using bank products was $64 \%$, compared to $54 \%$ for Slovak SMEs (SAFE, 2014). The ratio of rejected bank loan applications and unacceptable loan offers to total loan applications was $15.52 \%$ in Slovakia but only 5.28\% in the Czech Republic (EC, 2016b). These differences led us to expect that Slovak microenterprises might perceive greater impediments to satisfying their credit needs than would their Czech counterparts.

A vast number of studies confirm that larger firms are more likely to access credit than are smaller enterprises (Dong \& Men, 2014; Cenni, Monferra, Salotti, Sangiorgi, \& Torluccio, 2015). The same is true for access to financial services (Beck, Lu, \& Yang, 2015; de la Torre, Peria, \& Schmukler, 2010), and for perceptions about the size of obstacles to finance (Canton, Grilo, Monteagudo, \& Zwan, 2013; Casey \& O’Toole, 2014). But when it comes to cross-country comparisons of these issues there is no evidence. To close this research gap, this study aims to investigate whether differences exist between the perceptions of Slovak and Czech microenterprises in relation to the availability of financing options, and in relation to impediments to loans. The regions that microenterprises are located, are also considered to examine whether regional differences exist in the perceptions of Czech and Slovak microenterprises. Providing the first results on the differences in the perceptions of microenterprises will make a substantial contribution to this research area. The research also highlights financing options for micro-firms, from both their national financial markets and from international financing institutions. Being better informed about those financing opportunities will benefit all microenterprises. The results may also have policy implications for governments and for national and international lenders.

The rest of the paper is organized as follows. Section 1 briefly addresses the theoretical issues about the financial sources and credit obstacles facing microenterprises. Section 2 describes our methodology, including our choice of sample. Section 3 presents and discusses the results. The final section sums up the main conclusions and policy implications of the research.

\section{Literature review}

The rise in the importance of microenterprises' financing around the world has made them a popular research area in the recent academic literature. Their size gives them certain advantages and disadvantages over larger firms in finding and gaining financing options. But their flexible structure and small scale of operation can allow them to be very responsive to their customers' demands. This may provide some protection against economic crises and market fluctuations (Villanger, 2015), for example by quickly reacting to changing environments (Deller \& McConnon, 2009). Microenterprises usually seek only a small amount of 
credit and have very limited training activities in their operations (Panda, 2018). The proportion of nascent and closed firms is higher in micro-firms than in larger businesses. Most microenterprises have few plans to develop their businesses and have only limited income, profit and competencies (Villanger, 2015). In this regard, they need financing to continue their activities.

When it comes to financing choices, pecking order theory should be considered. This is because the existence of information asymmetry and high costs of external sources for SMEs make them first apply their internal resources, and then if needed they look for financing options from external sources (Serrasqueiro \& Caetano, 2015) that consist of informal and formal financing. Informal financing sources include customers, suppliers (Baptista, Ramalho, \& da Silva, 2006), pawnbrokers, moneylenders, private money houses, informal banks (Ayyagari, Demirguc-Kunt, \& Maksimovic, 2010), credit and gifts from family, friends, informal organizations, and trade credits. Formal financing sources involve credits from banks, credit cooperatives (Beck et al., 2015), micro finance institutions and international development organizations (Gbandi \& Amissah, 2014). Because of their insufficient savings, microenterprises are disposed to try to access credits from those informal and formal external sources. But the amount of external financing is more for larger ventures than smaller firms (Achleitner, Braun, \& Kohn, 2011) and the financial obstacles that microenterprises encounter in credit access are greater than those facing large enterprises (Saarela, Jokela, Eija-Riitta, Muhos, \& Leviakängas, 2016). According to Canton et al. (2013), the size of firms impacts on their perception of access to credit, with microenterprises having the lowest expectations.

Asymmetric information might be the underlying reason for the financial obstacles and the lower numbers of financing sources available to microenterprises. This is because these businesses are not listed in the stock market, provide less transparent information about their investments, abilities (Neuberger \& Rathke, 2009) and financial statements compared to large enterprises (Beck et al., 2015). Difficulties in reducing this information gap (Brown, Garguilo, \& Mehta, 2011) and the poor credit history of firms complicates the estimations of financial institutions regarding the probability of default by these firms (Canton et al., 2013). Incorrect calculations of the probability of default can influence financial providers' credit decisions and lead them to experience higher credit risks and to hold excessive numbers of non-performing loans in their portfolios.

Corresponding to the financing of microenterprises in Czech and Slovak Republic, the European Progress Microfinance Facility (EPMF), the European Investment Fund, the European Investment Bank, the European Commission, the COSME program, the EU/EBOR and Jasmine programs encourage micro finance organizations. These organizations also collaborate with local banks, leasing and investment institutions to support SMEs and provide micro credits for startups (Bondareva \& Zatrochova, 2014). The volume of funding for microenterprises in financial markets can be increased by creating more options, and governments other policy makers and NGOs can help reduce the gap between microenterprises and larger companies. By being aware of more of the formal and informal institutions that provide financing options for them, microentrepreneurs can also see that there may be adequate sources of finance for them in the financial market. However, Bondareva and Zatrochova (2014) and 
Sobeková Majková, Solík, and Sipko (2014) investigated Slovakian SMEs and resulted that high cost of credits and low amount of investments and state supports were the reasons for reduced credit access of Slovak firms. On top of that, while the amount of new SME lending differs from 3910 million euro to 4018 million euros between the years of 2014-2016 in Czech Republic, the amounts for new SME lending in Slovakia are 2603 and 3087 million euros respectively (OECD, 2018). This result makes it clear that, more funding amount exists in Czech market to finance SMEs in comparison with Slovakia. For this reason, it can be assumed in the hypothesis that more Czech micro firms can positively perceive the financing adequacy in their market than their Slovakian counterparts.

On the other hand, in comparison to larger firms, microenterprises have less equity (Neuberger \& Rathke, 2009), and collateral (Beck et al., 2015), fewer incomes (Larson \& Shaw, 2001), less capital and management capabilities (Villanger, 2015), limited earning potential, and a lack of opportunities to benefit from government subsidies (Eversole, 2004). These are also determinant factors for the high credit risk of microenterprises. Having borrowers with those disadvantages cause higher credit risks for financial providers because the probability that microenterprises can repay the credit decreases. To deal with the troubles of information asymmetry and credit risk, banks are reluctant to provide credits for microenterprises (de la Torre et al., 2010) or set too many criteria (Pandula, 2015), strict lending conditions and procedures (Garcia-Teruel, Martinez-Solano, \& Sanches-Ballesta, 2014) such as charging microenterprises higher rates (Villanger, 2015). All these practices change banks' approach on microenterprise financing and supports so they may not be interested with microenterprises' needs. Although these criteria differ regarding the characteristics of firms and entrepreneurs such as age, gender, education and experience (Cowling, Liu, \& Ledger, 2012) all microenterprises can perceive those activities negatively. Moreover, ease of doing business and the quality of business environment are other significant indicators that may impact on banks' approach on SMEs financing. For instance, worsening in business environment such as high tax and insurance costs and frequently changes in the law made Slovakian banks to create more difficulties for SMEs' financing (Sobeková Majková et al., 2014). The ranks from Ease of doing business index for Czech Republic and Slovakia are 30 and 39 respectively (World Bank, 2018). Those facts can be evidences that the conditions in Czech market are better than Slovak market. Hence, an assumption can be made in one of hypotheses of this study that Slovakian microenterprises more negatively perceive banks' approach on them than Czech firms do.

Obstacles to financing microenterprises in different countries can include monetary policies (Casey \& O’Toole, 2014), the quality of the financial institutions, the investment climate (Beck, Demirguc-Kunt, Laeven, \& Maksimovic, 2006), turbulent, hostile, business environments (Khan \& Quaddus, 2015), taxes and regulations (Berger \& Udell, 2006), legal, financial, market-based and macroeconomic factors, market structure and size, and financial risks in the markets (Panda, 2018). Canton et al. (2013) also argue that enterprises operating in countries with higher GDP per capita face reduced financial constraints. According to the World Bank (2016), GDP per capita in the Czech Republic was 18483.7 USD, while in Slovakia it was 16529.5 USD. By investigating 193 SMEs in Slovakia, Ivanová (2017) reveals that $77 \%$ of these firms encounter obstacles to 
gain credits from external sources because of the complicatedness in credit acceptance procedures and the strictness in criteria to evaluate their financial conditions. Belanova (2013) also showed that problems related with collateral, the size of firms, lack of profits, administrative burdens, and lengthy application procedures are the main obstacles to SMEs' accessing credit. Bondareva and Zatrochova (2014) noted that getting loans was becoming more difficult and expensive in Slovakia so these trends were limiting investment and access. In a wider comparative setting Canton et al. (2013) found that $46 \%$ of Slovak and $48 \%$ of Czech microenterprises perceived their credit access position as difficult. However, Canton et al. (2013) only considered bank loans in their analyses.

The successful development of economy is based on the efficient and stable performance of commercial banks (Gavurova, Belas, Kocisova, \& Kliestik, 2017). Operating in a well-developed banking sector is an important determinant of the availability of bank credits for microenterprises (Dong \& Men, 2014). The more branches a bank has the more credit it can provide (Beck et al., 2015; Y. Shen, M. Shen, Xu, \& Bai, 2009) and the wider is its range of products (Narender \& Venu, 2010) and the better is the fit with the needs of its clients (Wangmo, 2015). In addition the greater the degree of competition between banks, the better the lending conditions for microenterprises (Dong \& Men, 2014; Shen et al., 2009).

Relationship lending is another factor that might impact banks' approaches on microenterprises' financing. Information asymmetry between banks and microenterprises can be reduced by relationship lending (de la Torre et al., 2010), so banks can reduce collateral requirements (Rahman, Belas, Kliestik, \& Tyll, 2017) and offer these businesses more credit opportunities (Cenni et al., 2015). More and longer relationships provide banks with more and better data on SMEs (Neuberger \& Rathke, 2009; Cenni et al., 2015; Petersen \& Rajan, 1994). Banks therefore have more confidence in their decisions and may supply more credit.

Corresponding to the rigorous bank lending criteria for microenterprises, economies of scale play an important role in banks' lending activities. This is because smaller firms imply higher transaction, information, screening, monitoring costs for banks to evaluate credit rating of these firms (Okura, 2008). Moreover, administrating cost and providing credits to microenterprises is costly for banks (Bhattacharya \& Londhe, 2014). Banks also require relatively more collateral from firms to reduce information asymmetry, credit risks, supervising and monitoring costs (Yildirim, Akci, \& Eksi, 2013) and charge riskier firms higher interest rates (Blazy \& Weill, 2013). They apply these regulations to reimburse the amount of credit that is given to smaller enterprises, to reduce their credit risks (Berger, 1989), to protect themselves against credit default problems and potential losses (Rahman et al., 2017; Kliestik, Misankova, Valaskova, \& Svabova, 2018). If credit risk falls then banks may charge lower interest rates (Berger \& Udell, 1995), ask for less collateral, and provide better contract conditions for these enterprises (Menkhoff, Neuberger, \& Rungruxsirivorn, 2012), as negative perceptions of enterprises fall (Canton et al., 2013).

On the other side, depending on competition in finance (Shen et al., 2009; de la Torre et al., 2010) and banks' power in the market, (Ryan et al., 2014; Carbo, Rodriguez- 
Fernandez, \& Udell, 2009), their size (Berger, Goulding, \& Rice, 2014; Berger \& Black, 2011) and market shares (Mudd, 2013), influences banks' ability to raise finance costs (Canton et al., 2013; Cenni et al., 2015), or otherwise limit credit to microenterprises (Shen et al., 2009). As their borrowing costs rise microenterprises' investment opportunities fall relative to those of larger firms (Berger, 1989). This can be another reason why microenterprises tend to have inadequate internal resources and relatively few assets to collateralize for their credit needs.

When it comes to barriers to accessing external credit some additional factors may be influential. Most of microenterprises operate in less competitive environments, such as in rural areas (Thapa, 2015). So financial institutions in rural areas may have enhanced market power and provided relatively costly loans. In the absence of a well-organized financial structure, informal organizations may become more important sources of loans. But these tend to be relatively small, costly, and for short durations (Beck et al., 2015; Osei-Assibey et al., 2012). Some studies that focus on regional differences especially in business environment and SMEs' financing are also in existence in the literature. Because of the various factors and their impacts in market economy, regional differences come to existence (Koisova, Habanik, Vinglerova, \& Rozsa, 2017). In their study, Fila and Kučera (2015) reveal that amount of investments differ in various regions in Slovakia especially among Bratislava and others. Closeness of bigger cities, suppliers, customers, labor force, national sources, financing providers and technical opportunities have impact on the selection of the location of firms. By analyzing Slovakian SMEs, Koisova et al. (2017) prove that the perceptions of SMEs about sufficiency of banks products differ in various regions. Therefore, geographic location of firm can also play a determining role in the perception of financing availability and credit obstacles for microenterprises too. For those reasons, one of the hypotheses in this study will be set up as whether location has statistically significant influences on the perception of microentrepreneurs regarding financing availabilities and easiness of credit access.

\section{Aim, methodology and data}

The aim of the paper is to investigate and explore the differences between Czech and Slovak microenterprises regarding to their perception of availability of financing sources and the obstacles that they face when accessing these sources. In line with this selected purpose, four survey questions selected. Corresponding with the financing of SMEs, following two survey questions were selected: Question 1 "There is enough money on the financial markets to finance SMEs" and Question 2 "The Banks accept our needs and help us". Other survey questions that evaluate perceptions of microentrepreneurs regarding financing obstacles are Question 3 "Banks use too rigorous criteria when granting business loans" and Question 4 "SMEs have more barriers in gaining access from external sources (financial markets, bank loans and state loans)". The responses were scored using a five-point Likert scale: 1 - strongly agree, 2 - agree, 3 - hold no position, 4 - disagree, 5 - strongly disagree.

Five hypotheses were tested to explore the differences in perceptions. The literature review suggested that the Slovak microenterprises would perceive more obstacles to finance 
and would have more negative aspects on adequacy of financing than their Czech comparators. It is also suggested that since microenterprises located specifically in structurally affected regions are able to receive the funding through the special support programs, the entrepreneurs from these regions may perceive the financing tools as more accessible. The hypotheses were as follows:

H1: There is a statistically significant difference between the perceptions of Czech and Slovak microentrepreneurs regarding the adequacy of financial market funding sources for SMEs. The research presumes that Slovak microenterprises are more likely to disagree, or strongly disagree with the statement that "There is enough money on the financial markets to finance SMEs".

H2: A statistically significant difference exists between the opinions of Czech and Slovak microentrepreneurs in relation to the banks' approaches on SMEs financing. The research expects that more Slovak microenterprises would dissent from the view that "Banks accept our needs and help us".

H3: There is a statistically significant difference between the opinions of Czech and Slovak microentrepreneurs regarding the view that Banks use too rigorous criteria when granting business loans. The study presumes that more Slovak microenterprises agree or strongly agree with this statement.

H4: A statistically significant difference exists between the opinions of Czech and Slovak microentrepreneurs' on the statement that "SMEs face more barriers in gaining access to external sources (financial markets, bank loans and state loans". The study assumes that fewer Czech microentrepreneurs will agree or strongly agree with this statement.

H5: The location has a statistically significant impact on the opinions of Czech and Slovak microentrepreneurs' in relation to the volume and ease of access to finance. The zero-hypothesis assumes that the values are randomly distributed, it means that the location of the respondents does not affect their opinion.

To explore the differences between the Czech and Slovak microenterprises, Chi-Square and Pearson statistics were calculated and assessed at 5\% and 10\% confidence levels. P-values that are lower than these confidence levels cause us to accept the alternative hypotheses and to reject the null hypothesis of the non-existence of statistically significant differences in the perceptions of Czech and Slovak microenterprises. Moreover, to find out whether significant differences exist in the individual responses, the research employs the $\mathrm{Z}$ score test for 2 population proportions. The calculations were carried out using Microsoft Excel and free software, namely Social Science Statistics (n.d.). The Moran's I index was used for the verification of the hypothesis H5. Due to the small number of regions and the shape of the Slovak Republic the significance of the Moran coefficient was determined by the Monte Carlo method (99 999 permutations). In case of the Moran I index significance, local Moran coefficients is performed to identify the regions that cause spatial autocorrelation.

Table 1 depicts the structure of the Czech and Slovak microenterprises, that take part in our research. These microenterprises were represented by their founders and/or owners. Since the number of the employees in these enterprises ranks them as microenterprises (European Commission, 2016), the only question is whether the representatives of these companies are entrepreneurs. An entrepreneur is a person who is the main player to 
Table 1. The structure of the selected samples (source: own processing)

\begin{tabular}{|l|l|c|c|c|c|}
\hline \multirow{2}{*}{ Variables } & & \multicolumn{2}{c|}{ Czech } & \multicolumn{2}{c|}{ Slovak } \\
\cline { 3 - 6 } & & $\begin{array}{c}\text { Micro- } \\
\text { enterprises, } \\
\%\end{array}$ & $\begin{array}{c}\text { Number of } \\
\text { respondents }\end{array}$ & $\begin{array}{c}\text { Micro- } \\
\text { enterprises, } \\
\%\end{array}$ & $\begin{array}{c}\text { Number of } \\
\text { respondents }\end{array}$ \\
\hline $\begin{array}{l}\text { Length of } \\
\text { doing business }\end{array}$ & More than 10 years & $52.70 \%$ & 390 & $39.72 \%$ & 114 \\
\cline { 2 - 6 } Education & Less than 10 years & $47.30 \%$ & 350 & $60.28 \%$ & 173 \\
\cline { 2 - 6 } & Minimum university & $29.05 \%$ & 215 & $66.55 \%$ & 191 \\
\hline \multirow{2}{*}{ Gender } & Less than university & $70.95 \%$ & 525 & $33.45 \%$ & 96 \\
\cline { 2 - 6 } & Women & $72.97 \%$ & 540 & $68.64 \%$ & 197 \\
\hline $\begin{array}{l}\text { Age of } \\
\text { entrepreneur }\end{array}$ & More than 35 years old & $27.03 \%$ & 200 & $31.36 \%$ & 90 \\
\cline { 2 - 6 } & Less than 35 years old & $29.32 \%$ & 217 & $44.60 \%$ & 128 \\
\hline Total & & $100 \%$ & 740 & $100 \%$ & 287 \\
\hline
\end{tabular}

establish a new firm, who takes the financial risks of this activity in the hope of receiving a profit. Even though many risks exist in the creation of a new enterprise, an entrepreneur determines, creates or finds chances and takes all responsibilities to discharge them regarding required procedures (Mueller, Vlory, \& Von Siemens, 2012). On top of that, entrepreneurs are also owners of firms, who look for opportunities to create values and to drum up their business by determining and exploring new activities such as creating new products and services (OECD \& The European Commission, 2014). Since all the respondents of the investigated surveys in this study fulfill the described definitions, we consider them to be entrepreneurs, and the size of their enterprises allows to rank them as microentrepreneurs.

The datasets from the Czech Republic and Slovakia come from two separate questionnaire surveys on SMEs in these countries. The study included 1027 microenterprises (65.04\% of SMEs) from a total of 1579 Czech and Slovakian SMEs. The survey on the quality of the business environment facing Czech SMEs was administered in 2015. The online survey contained 52 questions. 1650 respondents from all 14 regions of the Czech Republic were selected randomly from the Albertina database, and after emails and phone calls 1141 of them completed the survey. 740 of the Czech SMEs (64.85\% of the respondents) were microenterprises. The stratified random sampling technique was applied. The firms were divided into different strata and a sample was selected representing the different strata randomly. The strata were determined by based on geographical regions. The firms were selected representing 14 regions of Czech Republic and 8 regions of Slovakia. The number of microenterprises included in the samples for each region was identified in proportion of the total number of microenterprises available in that region. The same methods were followed to collect data from Slovakian respondents. A random selection of appropriate companies from all 8 regions of Slovakia was made from free database of Slovak businesses accessible on www.vsetkyfirmy.sk. To collect data from Slovakian SMEs an online survey, "Financial Risk of SMEs in Slovakia", containing 60 questions was created and administered in 2016. 438 SMEs filled in this survey, of which 287 (65.52\%) were microenterprises. 


\section{Results and discussion}

Table 2 shows the results regarding the perceptions of Czech and Slovak microenterprises about the financing of SMEs by financial market and banks. As noted, Question 1 was intended to reveal the perceptions of microentrepreneurs in relation to the existence of adequate funding options in the financial market. A Chi-square test ( $p$-value $=0.00001$ ) confirms the existence of differences between Czech and Slovak microenterprises regarding financing of SMEs by financial markets. The $\mathrm{Z}$ score $(\mathrm{p}$-value $=0.0002)$ confirms that the differences between their perceptions are statistically significant.

Table 2. Differences in the perception of microenterprises' financing from financial markets (source: own processing)

\begin{tabular}{|l|c|c|c|}
\hline \multirow{2}{*}{$\begin{array}{c}\text { There is enough money on the financial } \\
\text { markets to finance SMEs }\end{array}$} & \multicolumn{2}{|c|}{ Question 1 } & \multirow{2}{*}{$\begin{array}{c}\text { P values from } \\
\text { Z score }\end{array}$} \\
\cline { 2 - 3 } & Czech Firms & Slovak Firms & 0.0010 \\
\hline Strongly agree and agree & $\begin{array}{c}153 \\
(20.68)\end{array}$ & $\begin{array}{c}87 \\
(30.31)\end{array}$ & 0.0000 \\
\hline Hold no position & $\begin{array}{c}366 \\
(49.46)\end{array}$ & $\begin{array}{c}80 \\
(27.88)\end{array}$ & \multirow{2}{*}{$\begin{array}{c}120 \\
(41.81)\end{array}$} \\
\hline Strongly disagree and disagree & $\begin{array}{c}221 \\
(29.86)\end{array}$ & 287 & \\
\hline Total number of microenterprises & 740 & \multicolumn{2}{|c|}{39.2954} \\
\hline Chí-square & \multicolumn{2}{|c|}{0.00001} \\
\hline P-values from Chi-Square & \multicolumn{2}{|c}{} \\
\hline
\end{tabular}

$41.81 \%$ of Slovak respondents strongly disagree or disagree with the opinion that enough funds exist in the market to finance SMEs, while only $29.86 \%$ of Czech microentrepreneurs have similar opinions to their Slovak counterparts. A significant and substantially higher proportion of Slovak microentrepreneurs feel there is insufficient support from financial market for them. According to these results, the study supports the corresponding hypothesis (H1). This result is similar with the finding of the studies of Bondareva and Zatrochova (2014) and Sobeková Majková et al. (2014) that report negative perception of Slovak entrepreneurs regarding amount of financing for Slovak SMEs.

In Table 3, aspects of microenterprises' views on bank financing are assessed by responses to Question 2. The results from the Chi-Square and $\mathrm{Z}$ scores ( $\mathrm{p}$-values $=0.000189$ and 0.0000 respectively) in this table confirm there are statistically significant differences between the two sets of perceptions. More than half the Slovak microenterprises have negative perceptions of the banks' approach on SMEs financing. Only $36.76 \%$ of Czech microenterprises have similar perceptions. We can accept the $\mathrm{H} 2$ hypothesis.

This result is in the same line with the finding of Sobeková Majková et al. (2014) that corroborate the worsening in Slovak Banks' approaches on SMEs. Because of deterioration in Slovak business environment, the banks in Slovakia could have tightened credit terms for microenterprises and could have made Slovak microentrepreneurs to feel banks' approach negatively. Having a lower ranking from Ease of Doing Business score for Slovakia can be an evidence for this situation. 
Table 3. Differences in the perception of microenterprises' financing from banks (source: own processing)

\begin{tabular}{|c|c|c|c|}
\hline \multirow{2}{*}{$\begin{array}{c}\text { Banks accept our needs and help } \\
\text { us }\end{array}$} & \multicolumn{2}{|c|}{ Question 2} & \multirow{2}{*}{$\begin{array}{l}\mathrm{P} \text { values from } \\
\mathrm{Z} \text { score }\end{array}$} \\
\hline & Czech Firms & Slovak Firms & \\
\hline Strongly agree and agree & $\begin{array}{c}249 \\
(33.65)\end{array}$ & $\begin{array}{c}77 \\
(26.83)\end{array}$ & 0.0348 \\
\hline Hold no position & $\begin{array}{c}219 \\
(29.59)\end{array}$ & $\begin{array}{c}64 \\
(22.30)\end{array}$ & 0.0187 \\
\hline Strongly disagree and disagree & $\begin{array}{c}272 \\
(36.76)\end{array}$ & $\begin{array}{c}146 \\
(50.87)\end{array}$ & 0.0000 \\
\hline Total number of microenterprises & 740 & 287 & \\
\hline Chí-square & \multicolumn{2}{|c|}{17.1451} & \\
\hline P-value from Chi-Square & \multicolumn{2}{|c|}{0.000189} & \\
\hline
\end{tabular}

Although many organizations help Slovak enterprises, in 2016 the level of government loan guarantees and business loans for SMEs and new businesses was higher in the Czech Republic than in Slovakia. The Czech Republic also has special loan guarantees and credits for startups and a SMEs bank that consults with these firms on their activities, namely the Czech-Moravian Guarantee and Development Bank. But Slovakia does not provide these financing options for Slovak enterprises (OECD, 2018). Because they were being informed about these financing options, Czech microentrepreneurs might have been less likely to disagree with the chosen statements. On the other hand, some studies observe that the amount of external financing is greater for older entrepreneurs (Achleitner et al., 2011; Cowling et al., 2012). This is because older entrepreneurs have had time to develop wider networks (Duman, 2009) and thus are better informed about the available financing options. In this study, 29.32\% of Czech microentrepreneurs are younger than 35, while the percentage for Slovak microentrepreneurs is $44.6 \%$. This may be part of the reason why Slovak microentrepreneurs feel that financial markets and banks do not provide enough financial support for them.

Furthermore, the longer a firm operates the longer is has had to gain knowledge of and experience with external financial institutions. Older microenterprises may also have more and better evidence of efficient past performances for lending officers to access (Neuberger \& Rathke, 2009). Hence, an older firm may have better access to loans (Osei-Assibey et al., 2012). In the data set $47.3 \%$ of Czech microenterprises were less than 10 years old, compared to $60.28 \%$ of Slovak firms. If that age difference translates into fewer loans for Slovak firms then this might also in part explain why a higher proportion of Slovak microenterprises disagree or strongly disagree with the view that financial markets have enough funds for them and banks helps them to fulfil their needs. In this regard, Slovakian government can corroborate with other countries to increase funding options for SMEs. Although, Slovakia has some agreements such as Agreement of European Economic Area and Norway grants the amount of grants for Slovakia is less than Czech Republic 113.1 and 184.5 million euros respectively (European Economic Agreement Grants and Norway Grants, 2018). For this reason, the Slovakian government can make more efforts to get higher amount of funds for SMEs. 
Table 4. Differences in the perception of bank loan obstacles (source: own processing)

\begin{tabular}{|c|c|c|c|}
\hline \multirow{2}{*}{$\begin{array}{l}\text { Banks use too rigorous criteria } \\
\text { when granting business loans }\end{array}$} & \multicolumn{2}{|c|}{ Question 3} & \multirow{2}{*}{$\begin{array}{c}\text { P values from } \\
Z \text { score }\end{array}$} \\
\hline & Czech Firms & Slovak Firms & \\
\hline Completely agree and agree & $\begin{array}{c}350 \\
(47.30)\end{array}$ & $\begin{array}{c}158 \\
(55.05)\end{array}$ & 0.0257 \\
\hline Hold no position & $\begin{array}{c}284 \\
(38.38)\end{array}$ & $\begin{array}{c}90 \\
(31.36)\end{array}$ & 0.0357 \\
\hline Completely disagree and disagree & $\begin{array}{c}106 \\
(14.32)\end{array}$ & $\begin{array}{c}39 \\
(13.59)\end{array}$ & 0.7641 \\
\hline Chí-square & \multicolumn{2}{|c|}{5.3915} & \\
\hline P-values from Chi-Square & \multicolumn{2}{|c|}{0.067491} & \\
\hline
\end{tabular}

Table 4 summarizes the findings on Slovak and Czech microenterprises' views on the difficulty of banks' lending criteria. Question 3 focuses on banks' lending terms. The Chi-square and $\mathrm{Z}$ score statistics are significant at the $10 \%$ confidence level (p-values = 0.067491 and 0.0257 respectively). There is a significant difference between the perceptions of Czech and Slovak microenterprises in relation to banks' lending conditions. $55.05 \%$ of Slovak entrepreneurs feel that banks' lending criteria are too strict while $47.3 \%$ of Czech enterprises feel the same. Owing to the higher percentage from Slovak respondents, the research corroborates the view that Slovak microenterprises perceive more obstacles in their access to bank loans than Czech microenterprises do. The result supports the $\mathrm{H} 3$ hypothesis.

Table 5. Differences in the perception of constraints from external sources (source: own processing)

\begin{tabular}{|c|c|c|c|}
\hline \multirow{2}{*}{$\begin{array}{l}\text { SMEs have more barriers in gaining access } \\
\text { to external sources (financial markets, } \\
\text { bank and state loans) }\end{array}$} & \multicolumn{2}{|c|}{ Question 4} & \multirow{2}{*}{$\begin{array}{c}\mathrm{P} \text { values from } \\
\mathrm{Z} \text { score }\end{array}$} \\
\hline & Czech Firms & Slovak Firms & \\
\hline Strongly agree and agree & $\begin{array}{c}346 \\
(46.76)\end{array}$ & $\begin{array}{c}179 \\
(62.37)\end{array}$ & 0.0000 \\
\hline Hold no position & $\begin{array}{c}277 \\
(37.43)\end{array}$ & $\begin{array}{c}71 \\
(24.74)\end{array}$ & 0.0001 \\
\hline Strongly disagree and disagree & $\begin{array}{c}117 \\
(15.81)\end{array}$ & $\begin{array}{c}37 \\
(12.89)\end{array}$ & 0.2380 \\
\hline Total number of microenterprises & 740 & 287 & \\
\hline Chí-square & \multicolumn{2}{|c|}{20.8692} & \\
\hline P-values from Chi-Square & \multicolumn{2}{|c|}{0.000029} & \\
\hline
\end{tabular}

Table 5 summarizes the findings of the study on Question 4. This assesses Czech and Slovak microentrepreneurs' views on barriers to external sources. The Chi-Square and Z scores are significant ( $\mathrm{p}$-values $=0.000029$ and 0.0000 respectively) and therefore the study confirms the $\mathrm{H} 4$ hypothesis. $62.37 \%$ of Slovak microentrepreneurs agree or strongly agree that SMEs face more obstacles to access loans from external sources, compared to $46.76 \%$ of Czech respondents. This fact also vindicates the assumption of the study in the $\mathrm{H} 4$ 
hypothesis that fewer Czech microentrepreneurs will agree or completely agree with this issue than their Slovakian counterparts. However, those results contradict the findings of Canton et al. (2013) that observed a similarity between Czech and Slovakian microenterprises' perceptions of credit access impediments.

Respondents in the questionnaire had the choice of one of five options that represented a degree of agreement with the statement. The point assessment (without prejudice to generality) was chosen to put the positive values in line with the positive replies, the negative with the disagreement and the zero point as an expression of the indifferent opinion. Since the data set included only the information about the region where the enterprise is located, the calculations were made for all regions in the Czech Republic and Slovakia. The values of answers for each region were set as an average value of respondents' responses from this region (Table 6).

Table 6. Average values of the answers of the respondents from the selected regions (source: own processing)

\begin{tabular}{|c|l|c|c|c|c|}
\hline State & \multicolumn{1}{|c|}{ Region } & Question 1 & Question 2 & Question 3 & Question 4 \\
\hline Slovakia & Žilinský & -0.3250 & -0.3750 & 0.5250 & 0.6000 \\
\hline Slovakia & Prešovský & 0.0769 & -0.3846 & 0.6923 & 1.1538 \\
\hline Slovakia & Trenciansky & 0.0000 & -0.3333 & 0.5238 & 0.5714 \\
\hline Slovakia & Košický & -0.2500 & -0.3750 & 0.5000 & 0.3750 \\
\hline Slovakia & Bratislavský & -0.0748 & -0.2789 & 0.5034 & 0.6395 \\
\hline Slovakia & Banskobystrický & 0.1429 & -0.6429 & 0.6429 & 0.7143 \\
\hline Slovakia & Trnavský & -0.1333 & 0.0000 & 0.8667 & 0.2000 \\
\hline Slovakia & Nitriansky & -0.1379 & -0.3103 & 0.5172 & 0.8276 \\
\hline Czechia & Liberecký & -0.2326 & 0.0233 & 0.3256 & 0.2558 \\
\hline Czechia & Ústecký & 0.5000 & 0.5000 & 0.5000 & 0.5000 \\
\hline Czechia & Praha & 0.1212 & 0.0303 & 0.5455 & 0.4242 \\
\hline Czechia & Karlovy Vary & 1.5000 & 0.0000 & -0.5000 & 0.0000 \\
\hline Czechia & Královehradecký & -0.1538 & 0.1538 & 0.3846 & -0.0769 \\
\hline Czechia & Středočeský & -0.1875 & 0.0000 & -0.0625 & 0.5000 \\
\hline Czechia & Plzeňský & -0.1250 & -0.1667 & 0.3750 & 0.5833 \\
\hline Czechia & Pardubický & -0.2692 & -0.2308 & 0.4615 & 0.4231 \\
\hline Czechia & Olomoucký & -0.0882 & -0.0588 & 0.3824 & 0.3529 \\
\hline Czechia & Moravskoslezský & -0.1534 & -0.1477 & 0.4716 & 0.3750 \\
\hline Czechia & Vysočina & -0.2308 & 0.0769 & 0.3077 & 0.5385 \\
\hline Czechia & Jihočeský & 0.1429 & -0.2857 & 0.4286 & 0.2857 \\
\hline Czechia & Zlínský & -0.1095 & -0.0697 & 0.3085 & 0.3980 \\
\hline Czechia & Jihomoravský & -0.1341 & -0.0488 & 0.2195 & 0.3780 \\
\hline
\end{tabular}


Table 7 presents test results of spatial autocorrelation in case of Slovakia. The results in case of questions 1 and 3 show negative spatial autocorrelation. The value of agreement with question 2 shows positive spatial autocorrelation. In case of the question 4 no spatial autocorrelation was identified, so the views of the respondents are not influenced by the location of their business.

Table 7. Results of spatial autocorrelation testing (source: own processing)

\begin{tabular}{|l|l|l|l|c|}
\hline & \multicolumn{1}{|c|}{ Question 1 } & \multicolumn{1}{|c|}{ Question 2 } & Question 3 & Question 4 \\
\hline Moran's I Index & -0.5521 & 0.2437 & -0.5978 & -0.2797 \\
\hline P-value & 0.02597 & 0.0015 & 0.00278 & 0.28571 \\
\hline $\begin{array}{l}\text { Spatial } \\
\text { autocorrelation }\end{array}$ & $\begin{array}{l}\text { Significant, } \\
\text { negative }\end{array}$ & $\begin{array}{l}\text { Significant, } \\
\text { positive }\end{array}$ & $\begin{array}{l}\text { Significant, } \\
\text { negative }\end{array}$ & Nonsignificant \\
\hline
\end{tabular}

The main source of the negative spatial autocorrelation in case of question 1 were Žilinský $(-0.2500)$ and Košický $(-0.3250)$ regions. The microentrepreneurs from these regions to a significantly lesser extent assume that there is enough money on the financial markets to finance SMEs. While Žilinský region is not listed in the list of the least developed regions of Slovakia that receive special aid, Košický region is (Central Office of Labour, Social Affairs and Family of Slovakia, 2018). We can also state that microentrepreneurs from the western (more developed) regions of Slovakia expressed less intense disagreement with the statement that the banks accept the needs of the entrepreneurs (question 2). The negative autocorrelation in case of the question 3 is caused by the average values in case of Bratislava region (0.5034) surrounded by the surprisingly high values from Trnava region $(0,8687$ - the highest value in the SR). In case of Slovakia we can confirm the hypothesis H5 in relation to Questions 1, 2 and 3. The results show that state support of the less developed regions does not affect the perception of the funding availability for microenterprises in Slovakia. Thus, regional differences exist in the perception of Slovakian microentrepreneurs regarding funding availability and banks approaches on microenterprise lending. Fila and Kučera (2015) find similar results that regional dissimilarities exist in Slovak business environment. On the contrary, Koisova et al. (2017) corroborates that there is no difference between regions of Slovakia regarding banks' lending criteria. Figure 1 shows the results of spatial autocorrelation testing of the map of Slovakia.

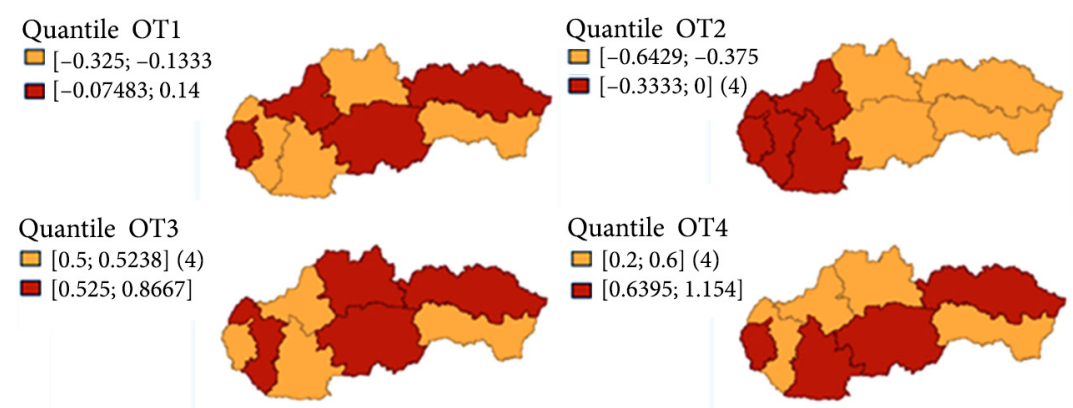

Figure 1. Results of spatial autocorrelation testing in case of Slovakia (source: own processing) 
Table 8 presents test results of spatial autocorrelation in case of Czechia. The results in case of question 3 show negative spatial autocorrelation. The value of agreement with question 1 shows positive spatial autocorrelation. In case of the questions 2 and 4 no spatial autocorrelation was identified, so the views of the respondents are not influenced by the location of their business.

Table 8. Results of spatial autocorrelation testing in case of Czechia (source: own processing)

\begin{tabular}{|l|c|c|c|c|}
\hline & \multicolumn{1}{|c|}{ Question 1 } & Question 2 & Question 3 & Question 4 \\
\hline Moran's I Index & 0.1649 & -0.0294 & -0.3409 & -0.1650 \\
\hline P-value & 0.03641 & 0.37354 & 0.01233 & 0.32276 \\
\hline $\begin{array}{l}\text { Spatial } \\
\text { autocorrelation }\end{array}$ & $\begin{array}{l}\text { Significant, } \\
\text { positive }\end{array}$ & Nonsignificant & $\begin{array}{l}\text { Significant, } \\
\text { negative }\end{array}$ & Nonsignificant \\
\hline
\end{tabular}

It is remarkable that in addition to significantly more positive replies, no spatial autocorrelation was found in relation to the statements that Banks accept our needs and help us in case of the Czech microenterprises. The main source of the positive spatial autocorrelation in case of question 1 were Královehradecký $(-0.1538)$ Pardubický $(-0.2692)$ regions. The main source of the negative spatial autocorrelation in case of question 3 was Ustecký region, but the results may be affected by a low number of the respondents from this region (2). Figure 2 shows the results of spatial autocorrelation testing in case of Czechia on the map.

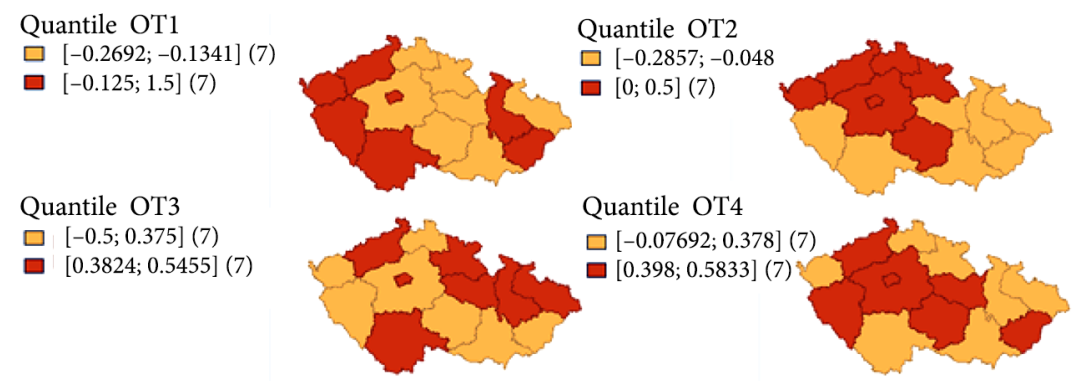

Figure 2. Results of spatial autocorrelation testing in case of Czechia (source: own processing)

While the regions with concentrated state support are mostly located in the eastern part and near the borders in the northern part of the Czechia, these regions do not demonstrate the sings of the spatial autocorrelation in case of the questions 1 and 4. Figure 3 shows the map of Economically problematic regions (Ministry of Local Development of Czech Republic, 2013).

In case of Czechia we can confirm the hypothesis H5 in relation to Questions 1 and 3. The results show that state support of the less developed regions does not affect the perception of the funding availability. On the other hand, perceptions of Czech microenterprises related with banks' lending criteria differ in different regions of Czech Republic. Although these differences exist in the regional level, some policies should be implemented by efficient players of Czech and Slovak Republic to make entrepreneurs perceive these issues in similar 


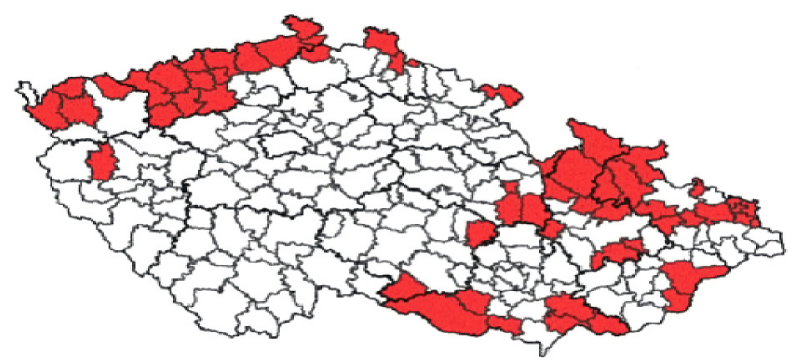

Figure 3. Results of spatial autocorrelation testing in case of Czechia (source: own processing)

manner. For instance, new microfinancing institutions can be set in both countries and they can mainly focuses on regional financing differences. Those institutions can aim to provide equal conditions for microenterprises from various geographical regions. Moreover, governments can control approaches and credit conditions of banks in microenterprises' financing to prevent the differences in banks' lending policies.

According to Beck et al. (2006), enterprises that operate in countries with higher scores on an economic freedom index face lower obstacles to access bank loans. The economic freedom index of Czech Republic is 74.2, while the score of Slovakia is 65.3 on a $0-100$ scale (Heritage, 2018a, 2018b). Hence, having a lower score from this index can be the reason why Slovakian microenterprises perceive more difficulties in gaining credits compared to Czech micro-firms. Moreover, some studies suggest that older firms encounter fewer credit constraints (Canton et al., 2013; Beck et al., 2006), make more credit applications (Presbitero \& Rabellotti, 2016) and get more credits than for younger firms (Mudd, 2013; Dong \& Men, 2014) According to Canton et al. (2013) firms that have been operating for less than 10 years have the worst perception of loan accessibility. The reason is that being in business for longer allows enterprises to get more experience and to contact more people and institutions that encourage them (Thapa, 2015). This may explain part of the difference in perceptions between Slovak and Czech microentrepreneurs.

In addition to the financial support provided by the Slovak government and other institutions such as the Microloan Program run by the Slovakian Business Agency, new microcredit or microfinance institutions, microenterprise development programs, non-profit financial intermediary organizations, microlending projects and programs, saving and credit cooperatives, intermediary programs, microenterprise zones, and microenterprise assistance programs can be set up or encouraged by government to ease access conditions and increase credit volumes. For instance, microfinance institutions do not ask for collateral that needs to be shown by borrowers to get credit (Ariful, Das, \& Rahman, 2017). These institutions encourage microenterprises that urgently need credits and provide a wide range of credit options for microenterprises to ease credit access conditions (Atmadja et al., 2016).

Furthermore, microenterprise development programs provide financial support for microenterprises (Thapa, 2015) and include technical and entrepreneurial education for microenterprises. By doing so, these programs motivate entrepreneurs to get into the markets to reduce the income gap between microenterprises and larger firms (Prentice, 2017). The Slovak government could create such programs not only to support mature or experienced 
firms but also to encourage less experienced, younger and startup microenterprises. The goverment could also increase the level of incentives and grants for microfinance organizations and microenterprises to develop them.

Nonprofit intermediaries also supply supervision and training support for poor entrepreneurs to continue their activities. These kinds of institutions also help entrepreneurs create and widen their networks by improving knowledge sharing with buyers, suppliers, rivals, and other organizations in their business environment. By doing so the performance of microenterprises can be significantly improved (Panda, 2018). Savings and Credit Cooperatives are other important institutions that supply a wide range of financial products including credits, insurance, leasing and money transfers (Brown et al., 2011). By creating microenterprise zones, governments can provide supports, subsidies, incentives and privileges for microenterprises to enhance microenterprise innovation, to create new products, reduce unemployment and improve technology competencies (Welsh, Munoz, Deng, \& Raven, 2013).

A majority of microlending programs assist for the development of microenterprises (Jha \& Depoo, 2017). The Slovak government could create a microlending project that provides loans for unemployed entrepreneurs and for micro-firms that have poor credit histories. In addition, microenterprise performance can be improved by microenterprise programs, training, external support and financial resources (Munoz, Welsh, Chan, \& Raven, 2015). For instance, a microcredit platform such as network can be set up by government to bring together the financing institutions and micro firms. In order fulfill their needs, microenterprises can provide their business plans to these organizations and in case of being accepted, they can not only gain financial supports but also can get financial advising and training activities. In this case, SMEs can also be more informed how they can use these credits to have higher amount of returns from their investment. Moreover, advisors and trainers can increase firms' awareness to find more funding opportunities, can give them more clues for sufficient credit application, can improve their financial literacy and inform them for new regulations about financing conditions. Some role models such as famous entrepreneurs also can present their story in conferences and workshops that highlight how these entrepreneurs cope with obstacles of credit access. Financing institutions can also be participants in these activities.

Furthermore, having an efficient creditor protection system decreases the financing gap between smaller and larger enterprises (Galindo \& Micco, 2007). In this regard, creating better protection rights for microenterprises can also increase their financing options and reduce their financing obstacles. The banks and the government can also take a concrete step together to reduce financing obstacles for microenterprises. Banks can require easier lending conditions for businesses by the support of the government that plays such a guarantor role in lending. Moreover, the state can provide tax concession for banks, bring up some standards in loan and credit application procedures and make stabilization in the laws to reduce banks' burden in credit extension. For instance, the number of required documents and the number of days in credit application can be identified to reduce confusion in these processes. By implementing those regulations, ease of getting credit and amount of loans for microenterprises can also be increased. All the policy options suggested for the Slovak Government and Slovak financial institutions could be replicated by the Czech government and Czech financial institutions. 


\section{Conclusions}

The existence of readily accessible, adequate loan options from external financing institutions has a crucial importance for microenterprises to carry on their activities, to grow, and to be more competitive. In this context, this research aims to discover whether the perceptions of microentrepreneurs differ across countries with respect to credit options and loan conditions. In line with this objective, the research examined 740 Czech and 287 Slovak microenterprises, making comparisons using Chi-Square and $\mathrm{Z}$ score statistics.

One of the simplest conclusions can be drawn as, relatively more Slovak than Czech microenterprises perceive problems with the available sources of finance. The reasons why Slovakian microenterprises have faced with this issue could be having less experienced, less informed and younger owners, having less amount of investments, government guaranteessupports, business loans and microfinancing institutions. Another important conclusion is that more Slovak microenterprises negatively feel banks' aspects on them in comparison with Czech micro-firms. Business environment and ease of doing business might be the reason why more Slovakian entrepreneurs negatively perceive banks' approach.

Considering to the constraints that microenterprises face in financing from external sources, it can be concluded that Slovakian microenterprises perceive more difficulties in gaining credits than Czech micro firms do. The reasons for these difficulties that more Slovakian firms encounter might be having lower payment discipline especially in credit repayment, being exposed to higher interest rates and higher rejection rate in credit application, having lower score from GDP, having more complicated credit acceptance procedures and administrative burdens. Those issues make Slovakian micro firms to perceive raised financing obstacles.

When it comes to the barriers that microenterprises encounter in bank financing, Slovakian microenterprises are more likely to perceive them as financing obstacles in comparison with Czech micro-firms. This is because, compared to Czech microenterprises they work with less economic freedom and doing business in their market is not easier. On the other hand, facing with higher costs in taxes, insurances and credit evaluation might have made Slovakian banks to charge microenterprises with higher costs and to apply tight credit conditions for those firms. Moreover, everchanging regulations in law might be caused unsecured conditions. To cope with these issues banks might have applied some polities that raise difficulties for Slovak firms.

Furthermore, to assess the impact of location factor on the perception of microenterprises, the Moran's I index was applied. The results from this index confirm that constraints in microenterprises' financing do not differ for microenterprises from different regions. But, perceptions of financing adequacy for Czech and Slovak microentrepreneurs differ in relation with the location of their firms.

To overcome these problems, the Slovak government should provide more grants, subsidies and funding opportunities for microenterprises, establish new regional microfinance institutions to reduce differences in various regions. Besides a control mechanism can be set for banks by the government to investigate differences in their lending policies for each region. The government can also create new programs, projects and better working environ- 
ment, reduce difficulties in doing business for microenterprises and encourage the existing organizations. In doing so Slovakia could raise its GDP, its workforce, its economic freedom index score and can generate more income, present quality business environment and easier credit access conditions for microentrepreneurs.

The results of this study can make policy makers to close the financing gap between microenterprises in these countries. Even though, Czech microenterprises more positively perceive the banks' approach, funding options and credit availability in their country, lending conditions and amount of financial support can still be improved. For this reason, the government and all financing organizations in this market also should take some responsibilities to enhance credit availability and to ease credit access of microenterprises.

Although the research finds significant differences between the selected variables, it only covers Slovak and Czech microenterprises. The extent of data collection and use of online surveys are further limitations because they only give a snapshot of respondents' perceptions. Further studies could focus on a wider geographical area, cover additional sizes of enterprise, involve more variables, more enterprises and a wider range of statistical methods. Moreover, other financing options and financing institutions could be considered by further studies. All possible obstacles that firms meet in lending could also be included by new scientific researches to look these constraints from a broad perspective. These would provide a more comprehensive picture of the financing of SMEs.

\section{Acknowledgements}

This work was supported by the Internal Grant Agency of Univerzita Tomáše Bati ve Zlíně, Project No. IGA/FaME/2019/002, “The role of institutional environment in fostering entrepreneurship".

\section{Author contributions}

Mehmet Civelek was responsible to design the work, to make analyses, to make comments for the results and to write all drafts of the article to be published.

Aleksandr Ključnikov was responsible to interpret and collect the data. He was also responsible to make analyses for Spatial correlation.

Peter Krištofík was responsible to find related studies from the literature to support the results and to control all analyses.

Zoltán Rozsa was responsible to review final versions of the study, to check whether the study had contend integrity and to revise the article in case of finding inaccurate things.

\section{Disclosure statement}

The authors declare that they do not have any competing financial, professional, or personal interests from other parties. 


\section{References}

Achleitner, A. K., Braun, R., \& Kohn, K. (2011). New venture financing in Germany: Effects of firm and owner characteristics. Zeitschrift Für Betriebswirtschaft, 81(1), 263-294. https://doi.org/10.1007/s11573-011-0441-3_

Ariful, C. H., Das, A., \& Rahman, A. (2017). The effectiveness of micro-credit programmes focusing on household income, expenditure and savings: Evidence from Bangladesh. Journal of Competitiveness, 8(2), 34-44. http://doi.org/10.7441/joc.2017.02.03

Atmadja, A. S., Jen-Je, S., \& Sharma, S. (2016). Examining the impact of microfinance on microenterprise performance (Implications for women-owned microenterprises in Indonesia). International Journal of Social Economics, 43(10), 962-981. https://doi.org/10.1108/IJSE-08-2014-0158

Ayyagari, M., Demirguc-Kunt, A., \& Maksimovic, V. (2010). Formal versus informal finance: Evidence from China. The Review of Financial Studies, 23(8), 3048-3097. https://doi.org/10.1093/rfs/hhq030

Baptista, J., Ramalho, J., \& da Silva, J. (2006). Understanding the microenterprise sector to design a tailor-made microfinance policy for Cape Verde. PEJ, 5, 225-241. https://doi.org/10.1007/s10258-006-0004-7

Beck, T., Demirguc-Kunt, A., Laeven, L., \& Maksimovic, V. (2006). The determinants of financing obstacles. Journal of International Money and Finance, 25, 932-952. https://doi.org/10.1016/j.jimonfin.2006.07.005

Beck, T., Lu, L., \& Yang, R. (2015). Finance and growth for microenterprises: Evidence from rural China. World Development, 67, 38-56. http://doi.org/10.1016/j.worlddev.2014.10.008

Belanova, K. (2013). Access to finance of small and medium sized enterprises in Slovakia. Economic Review, 42(3), 277-290. Retrieved from http://old.euba.sk/department-for-research-and-doctoralstudies/economic-review/preview-file/er3_2013_belanova_fulltext-13603.pdf

Berger, A. N., \& Udell, G. (2006). A more complete conceptual framework for SMEs finance. Journal of Banking and Finance, 30(11), 2945-2966. https://doi.org/10.1016/j.jbankfin.2006.05.008

Berger, A. N., \& Udell, G. (1995). Relationship lending and lines of credit in small firm finance. The Journal of Business, 68(3), 351-381. Retrieved from http://www.jstor.org/stable/2353332 https://doi.org/10.1086/296668

Berger, A. N., \& Black, L. K. (2011). Bank size, lending technologies, and small business finance. Journal of Banking \& Finance, 35(3), 724-735. https://doi.org/10.1016/j.jbankfin.2010.09.004

Berger, A. N., Goulding, W., \& Rice, T. (2014). Do small businesses still prefer community banks? Journal of Banking \& Finance, 44, 264-278. https://doi.org/10.1016/j.jbankfin.2014.03.016

Berger, M. (1989). Giving women credit: The strengths and limitations of credit as a tool for alleviating poverty. World Development, 17(7), 1017-1032. https://doi.org/10.1016/0305-750X(89)90165-4

Bhaird, C., \& Lucey, B. (2010). Determinants of capital structure in Irish SMEs. Small Business Economics, 35, 357-375. https://doi.org/10.1007/s11187-008-9162-6

Bhattacharya, S., \& Londhe, B. R. (2014). Micro entrepreneurship: Sources of finance \& related constraints. In Procedia Economics and Finance, 11, Symbiosis Institute of Management Studies Annual Research Conference (SIMSARC13) (pp. 775-783). https://doi.org/10.1016/S2212-5671(14)00241-X

Blazy, R., \& Weill, L. (2013). Why do banks ask for collateral in SME lending? Applied Financial Economics, 23(13), 1109-1122. https://doi.org/10.1080/09603107.2013.795272

Bondareva, I., \& Zatrochová, M. (2014). Financial support for the development of SMEs in the Slovak Republic. Procedia - Social and Behavioral Sciences, 110, 541-548. https://doi.org/10.1016/j.sbspro.2013.12.898

Brown, A., Garguilo, S., \& Mehta, K. (2011). The relentless pursuit of financial capital for Microenterprises: Importance of trust and social capital. International Journal for Service Learning in 
Engineering, 6(2), 78-97. Retrieved from https://www.researchgate.net/profile/Khanjan_Mehta/ publication/257142786

Canton, E., Grilo, I., Monteagudo, J., \& Zwan, P. W. (2013). Perceived credit constraints in The European Union. Small Business Economics, 41, 701-715. https://doi.org/10.1007/s11187-012-9451-y

Carbo, S., Rodriguez-Fernandez, F., \& Udell, G. (2009). Bank market power and SME financing constraints. Review of Finance, 13(2), 309-340. https://doi.org/10.1093/rof/rfp003

Casey, E., \& O’Toole, C. (2014). Bank lending constraints, trade credit and alternative financing during the financial crisis: Evidence from European SMEs. Journal of Corporate Finance, 27, 173-193. https://doi.org/10.1016/j.jcorpfin.2014.05.001

Cenni, S., Monferra, S., Salotti, V., Sangiorgi, M., \& Torluccio, G. (2015). Credit rationing and relationship lending: Does firm size matter? Journal of Banking \& Finance, 53, 249-265. https://doi.org/10.1016/j.jbankfin.2014.12.010

Central Office of Labour, Social Affairs and Family of Slovakia. (2018). Retrieved from https://www. upsvr.gov.sk/kontakt.html?page_id=233

Cowling, M., Liu, W., \& Ledger, A. (2012). Small business financing in the UK before and during the current financial crisis. International Small Business Journal, 30(7), 778-800. https://doi.org/10.1177/0266242611435516

Daskalakis, N., Jarvis, R., \& Schizas, E. (2013). Financing practices and preferences for micro and small firms. Journal of Small Business and Enterprise Development, 20(1), 80-101. https://doi.org/10.1108/14626001311298420

De la Torre, A., Pería, M. S. M., \& Schmukler, S. L. (2010). Bank involvement with SMEs: Beyond relationship lending. Journal of Banking \& Finance, 34, 2280-2293. https://doi.org/10.1016/j.jbankfin.2010.02.014_

Deller, S., \& McConnon, J. (2009). Microenterprises and economic growth: A panel study of the US States 1977-1997. Applied Economics Letters, 16(13), 1307-1312. https://doi.org/10.1080/13504850701367361

Dong, Y., \& Men, C. (2014). SME financing in emerging markets: Firm characteristics, banking structure and institutions. Emerging Markets Finance \& Trade, 50(1), 120-149. http://doi.org/10.2753/REE1540-496X500107

Duarte, F. D., Gama, A. P. M., \& Esparanca, J. S. (2017). Collateral-based in SME lending, The role of business collateral and personal collateral in less developed countries. Research in International Business and Finance, 39, 406-422. https://doi.org/10.1016/j.ribaf.2016.07.005

Duman, A. (2009). Access to credit: Microenterprises in Turkey. Working Papers in Economics, 9(5), 1-13. Retrieved from http://hdl.handle.net/10419/175906

EC. (2016a). European Commission SBA Fact Sheet. Czech Republic. Retrieved from https://ec.europa. $\mathrm{eu} / \mathrm{docsroom} /$ documents/22382/attachments/7/translations/en/renditions/pdf $+\& \mathrm{~cd}=2 \& \mathrm{hl}=\mathrm{tr} \& \mathrm{ct}=$ $\mathrm{clnk} \& \mathrm{gl}=\mathrm{cZ}$

EC. (2016b). European Commission SBA Fact Sheet. Slovakia. Retrieved from https://ec.europa.eu/ docsroom/documents/22382/attachments/31/translations/en/renditions/pdf $+\& \mathrm{~cd}=1 \& \mathrm{hl}=\mathrm{tr} \& \mathrm{ct}=$ $\mathrm{clnk} \& \mathrm{gl}=\mathrm{cZ}$

European Commission. (2016). New SME definition and a model declaration to be used when applying to SME support schemes. Retrieved from https://ec.europa.eu/digital-single-market/en/news/newsme-definition-user-guide-and-model-declaration

European Economic Agreement Grants and Norway Grants. (2018). Retrieved from https://eeagrants. org/Where-we-work

Eversole, R. (2004). Change makers? Women's microenterprises in a Bolivian City. Gender Work and Organization, 11(2), 123-142. https://doi.org/10.1111/j.1468-0432.2004.00225.x 
Fila, M., \& Kučera, J. (2015). Innovation performance of the Slovak Republic and its regional disparities in innovation management and corporate sustainability. IMACS, 2015, 39-51. Retrieved from http:// imacs.vse.cz/wp-content/uploads/2015/08/Proceedings-IMACS-2015-fullpapers-APA.pdf\#page=42

Galindo, A. J., \& Micco, A. (2007). Creditor protection and credit response to shocks. The World Bank Economic Review, 21(3), 413-438. https://doi.org/10.1093/wber/lhm016

Garcia-Teruel, P. J., Martinez-Solano, P., \& Sanchez-Ballesta, J. P. (2014). Supplier financing and earnings quality. Journal of Business Finance \& Accounting, 41(9-10), 1193-211. https://doi.org/10.1111/jbfa.12090

Gavurova, B., Belas, J., Kocisova, K., \& Kliestik, T. (2017). Comparison of selected methods for performance evaluation of Czech and Slovak commercial banks. Journal of Business Economics and Management, 18(5), 852-876. https://doi.org/10.3846/16111699.2017.1371637

Gbandi, E. C., \& Amissah, G. (2014). Financing options for small and medium enterprises (SMEs) in Nigeria. European Scientific Journal, 10(1), 327-340. Retrieved from https://www.eujournal.org/ index.php/esj/article/view/2565/2426

Heritage. (2018a). Economic freedom index. Czech Republic. Retrieved from https://www.heritage.org/ index/country/czechrepublic

Heritage. (2018b). Economic freedom index. Slovakia. Retrieved from https://www.heritage.org/index/ country/slovakia

Jha, R., M. A., \& Depoo, T. (2017). Role of microenterprises in recovering U.S. economy- post 2008 financial crisis. The Journal of Applied Business and Economics, 19(3), 9-28. Retrieved from https:// search.proquest.com/docview/1927524915? accountid=15518

Ivanová, E. (2017). Barriers to the development of SMEs in the Slovak Republic. Oeconomia Copernicana, 8(2), 255-272. https://doi.org/10.24136/oc.v8i2.16

Khan, A., \& Quaddus, M. (2015). Examining the influence of business environment on socio-economic performance of informal microenterprises. International Journal of Sociology and Social Policy, 35(3/4), 273-288. https://doi.org/10.1108/IJSSP-02-2014-0016

Kliestik, T., Misankova, M., Valaskova, K., \& Svabova, L. (2018). Bankruptcy prevention: New effort to reflect on legal and social changes. Science and Engineering Ethics, 24(2), 791-803. https://doi.org/10.1007/s11948-017-9912-4

Koisova, E., Habanik, J., Virglerova, Z., \& Rozsa, Z. (2017). SMEs financing as an important factor of business environment in Slovak Republic regions. Montenegrin Journal of Economics, 13(2), 129140. https://doi.org/10.14254/1800-5845/2017.13-2.8

Kozubikova, L. (2016). Differences in innovativeness and risk-taking between microenterprises and SMEs: Czech Republic Case Study. Actual Problems of Economics, 3(177), 167-177. Retrieved from https://search.proquest.com/docview/1781553740?accountid=15518

Larson, D. W., \& Shaw, T. K. (2001). Issues of microenterprise and agricultural growth: Do opportunities exist through forward and backward linkages? Journal of Developmental Entrepreneurship, 6(3), 203-220.

Menkhoff, L., Neuberger, D., \& Rungruxsirivorn, O. (2012). Collateral and its substitutes in emerging markets lending. Journal of Banking and Finance, 36, 817-834.

https://doi.org/10.1016/j.jbankfin.2011.09.010

Ministry of Local Development of Czech Republic. (2013). Strategie regionálního rozvoje ČR 2014-2020. Retrieved from https://www.mmr.cz/getmedia/08e2e8d8-4c18-4e15-a7e2-0fa481336016/SRR-20142020.pdf, picture 23

Mudd, S. (2013). Bank structure, relationship lending and small firm access to finance: A cross-country investigation. Journal of Financial Services Research, 44(2), 149-174.

https://doi.org/10.1007/s10693-012-0140-4 
Munoz, J. M., Welsh, D. H. B., Chan, S., \& Raven, P. V. (2015). Microenterprises in Malaysia: A preliminary study of the factors for management success. International Entrepreneurship and Management Journal, 11(3), 673-694. https://doi.org/10.1007/s11365-014-0302-y

Narender, V., \& Venu, L. (2010). Challenges of lending and credit assessment for SMEs in India. Management Prudence Journal, 1(2), 66-75. Retrieved from https://search.proquest.com/docview/1478 031634 ? accountid $=15518$

Neuberger, D., \& Rathke, S. (2009). Microenterprises and multiple bank relationships: The case of professionals. Small Business Economics, 32, 201-229. https://doi.org/10.1007/s11187-007-9076-8

OECD \& The European Commission. (2014). The missing entrepreneurs: Policies for inclusive entrepreneurship in Europe. OECD Publishing. https://doi.org/10.1787/9789264213593.en

OECD. (2018). Financing SMEs and entrepreneurs: an OECD scoreboard. Paris: OECD Publishing. https://doi.org/10.1787/fin_sme_ent-2018-en

Okura, M. (2008). Firm characteristics and access to bank loans: An empirical analysis of manufacturing SMEs in China. International Journal of Business and Management Science, 1(2), 165-186. Retrieved from https://search.proquest.com/docview/89160990?accountid=15518

Osei-Assibey, E., Godfred, A., Bokpin, D., \& Twerefou, K. (2012). Microenterprise financing preference: Testing $\mathrm{POH}$ within the context of Ghana's rural financial market. Journal of Economic Studies, 39(1), 84-105. https://doi.org/10.1108/01443581211192125

Panda, D. K. (2018). Entrepreneurial orientation, intermediation services, microfinance, and microenterprises. Managerial and Decision Economics, 39, 253-265. https://doi.org/10.1002/mde.2900

Pandula, G. (2015). Bank finance for small and medium-sized enterprises in Sri Lanka: issues and policy reforms. Studies in Business and Economics, 10(2), 32-43. https://doi.org/10.1515/sbe-2015-0018

Petersen, M. A., \& Rajan, R. G. (1994). The benefits of lending relationships: Evidence from small business data. The Journal of Finance, 49(1), 3-37. https://doi.org/10.1111/j.1540-6261.1994.tb04418.x

Prentice, R. (2017). Microenterprise development, industrial labor and the seductions of precarity. Critique of Anthropology, 37(2), 201-222. https://doi.org/10.1177/0308275X17694944

Presbitero, A. F., \& Rabellotti, R. (2016). The determinants of firm access to credit in Latin America: Micro characteristics and market structure. Economic Notes 3 - Review of Banking, Finance and Monetary Economics, 45(3), 445-472. https://doi.org/10.1111/ecno.12069

Rahman, A., Belas, J., Kliestik, T., \& Tyll, L. (2017). Collateral requirements for SME loans: Empirical evidence from the Visegrad Countries. Journal of Business Economics and Management, 18(4), 650-675. https://doi.org/10.3846/16111699.2017.1357050

Ryan, R. M., O’Toole, C. M., \& McCann, F. (2014). Does bank market power affect SME financing constraints? Journal of Banking \& Finance, 49, 495-505. https://doi.org/10.1016/j.jbankfin.2013.12.024

Saarela, M., Jokela, H., Eija-Riitta, N., Muhos, M., \& Leviäkangas, P. (2016). The firm level impacts of local public funding to microenterprises. International Journal Innovation and Learning, 19(3), 299-313. https://doi.org/10.1504/IJIL.2016.075656

SAFE. (2014). Survey on the access to finance of enterprises. Analytical Report. Retrieved from https:// ec.europa.eu/docsroom/documents/7504/attachments/1/translations/en/renditions/native

Serrasqueiro, Z., \& Caetano, A. (2015). Trade-off theory versus pecking order theory: Capital structure decisions in a peripheral region of Portugal. Journal of Business Economics and Management, 16(2), 445-466. https://doi.org/10.3846/16111699.2012.744344

Shen, Y., Shen, M., Xu, Z., \& Bai, Y. (2009). Bank size and small- and medium-sized enterprise (SME) lending: Evidence from China. World Development, 37(4), 800-811. https://doi.org/10.1016/j.worlddev.2008.07.014

Sobeková Majková, M., Solík, J., \& Sipko, J. (2014). The analysis of chosen business obstacles and problems with the financing of young entrepreneurs in Slovakia. Economics and Sociology, 7(3), 90-103. https://doi.org/10.14254/2071-789X.2014/7-3/7 
Social Science Statistics. (n.d.). Chi-Square and Z score calculator for 2 population proportions. Retrieved from http://www.socscistatistics.com/tests

Technology Agency of Czech Republic. (2015). Technology agency of Czech Republic and its programmes. Retrieved from https://www.tacr.cz/dokums_raw/media/brochure_TACR_ENG_2.pdf

Technology Agency of Czech Republic. (n.d.). Retrieved from https://www.tacr.cz/index.php/en/abouttacr.html

Thapa, A. (2015). Determinants of microenterprise performance in Nepal. Small Business Economy, 45, 581-594. https://doi.org/10.1007/s11187-015-9654-0

Villanger, E. (2015). Entrepreneurial abilities and barriers to microenterprise growth: A case study in Nepal. The Journal of Entrepreneurship, 24(2), 115-147. https://doi.org/10.1177/0974927615586888

Wangmo, C. (2015). Small Medium Enterprise (SME) bank financing constraints in developing countries: A case study of Bhutan. International Journal of Arts \& Sciences, 8(5), 569-590. Retrieved from https://search.proquest.com/docview/1764690575?accountid=15518

Welsh, D. H. B., Munoz, J. M., Deng, S., \& Raven, P. V. (2013). Microenterprise performance and microenterprise zones (MEZOs) in China. Management Decision, 51(1), 25-40. https://doi.org/10.1108/00251741311291292

World Bank. (2016). GDP Statistics. Retrieved from https://data.worldbank.org/indicator/NY.GDP. PCAP.CD

World Bank. (2018). Retrieved from https://data.worldbank.org/indicator/IC.BUS.EASE.XQ

Yildirim, H. S., Akci, Y., \& Eksi, I. H. (2013). The effect of firm characteristics in accessing credit for SMEs. Journal of Financial Services Marketing, 18(1), 40-52. https://doi.org/10.1057/fsm.2012.28 